\title{
Financial and Operational Problems of Micro Enterprise in Baglung and Parbat Districts
}

\author{
Bir Bahadur Karki, PhD \\ Associate Professor \\ Faculty of Management, Prithvi Narayan Campus, Pokhara, Tribhuvan University, Nepal \\ Email: bir.karki@prnc.tu.edu.np
}

DoI: https://doi.org/10.3126/dristikon.v10i1.34540

\begin{abstract}
The paper aims to explore major problems face by the micro enterprises. The objective of the research is to identify problems of micro enterprise in Baglung and Parbat districts. This study is based on mixed research design (quantitative and qualitative research). Data and information are collected through primary sources. Primary data are collected through structured questionnaire, focus group discussion, observations and field visit. Purposive and convincing sampling methods are used for selecting enterprises and entrepreneur respectively. A few statistical tools such as percentage are used for data analysis. There is not found such types of research work i.e. the financial and operational problems of micro enterprises in a particular area or district. After field visiting of micro enterprises in Parbat and Baglung district and focus group discussion with micro enterprises, it is found that micro enterprises have been facing various types of problems. Micro enterprises have been conducting with various problems such as production or input related problems and financial or economic related problems etc. Lack of working capital, higher interest rate on loan, not easily available raw materials in local market, problems regarding cold storage and warehouse, lack of adequate infrastructure like road, electricity, water, lack of other input materials for production, lack of skilled labour etc. are major problems faced by entrepreneurs as well as enterprises. Most of the micro enterprises are operating with a little fund, local resources and local skills. Government of Nepal should be managed special program to solve such types of problems of micro enterprises.
\end{abstract}

Keywords: micro enterprise, micro entrepreneur, financial and operational problems, micro enterprise group

\section{Introduction}

\section{Background}

Nepal is an underdeveloped country, so that most of the development activities are found in primitive stage. Big or large industries, huge investment in the business sectors are not found in Nepal due to lack of sophisticated technology, competent and skillful human resources, well developed infrastructure and market. In this context, micro enterprises and/or small businesses might be appropriate for utilization of local resources, local skills and local or moderate level technology. Most of the Nepalese people live in rural and remote area, they are 
not able to establish and operate middle or large-scale industries. Rural people do not have adequate capital fund, not able to obtain latest or modern technology and skill and not able to access well established infrastructure. For economic development of the nation, micro and small enterprises are more appropriate enterprise rather than medium and large scale enterprisein developing countries like in Nepal (Karki, 2013).

Baglung and Parbat both districts are located under Gandaki Province and Dhawalagiri zone. Government of Nepal (GON) categories the whole district under different headings like high remote area, remote area, less developed area and developed area or districts. Baglung district is locted under remote area district and Parbat district is less developed district/area.

Industrial Enterprise Act, 2020 defines that a micro enterprise means the enterprise having met the following conditions:- - Where investment is up to twenty hundred thousand rupees as fixed capital except the house or land - Where the entrepreneur himself/ herself engaged in operation management $\bullet$ Where there are up to nine workers including the entrepreneur - Where the annual financial transaction is less than ten million rupees, and if an instrument with engine is used, the electric motor or other oil engine capacity has to be less than 20 kilowatt (www.lawcommission.gov.np/industrial enterprises act, 2020). It is based on Industrial Policy 2010.

Even if the aforesaid conditions have been fulfilled, an enterprise that requires permission, liquors, beer, cigarette, biri, or other tobacco goods or materials shall not be deemed to be a micro enterprise. Moreover, if an enterprise registered once as micro enterprise is upgraded as other industry; such an industry shall not be listed as a micro enterprise.

Directives of operation of Micro-Enterprise Development for Poverty Alleviation (MEDPA) 2070 (including third amendenment, 2075) clearly define Enterprise Development Facilitator (EDF), Common Faciliatator Center (CFC), Start and Improve Your Business (SIYB) and Micro-Enterprise Creation and Development (MECD), Business Development Service Provider Organization (BDSPO), people under below poverty line, ultra-poor, target groups etc. (GON, MOICS, 2075).

The government of Nepal (GoN) and United Nations Development Programme (UNDP) started Micro Enterprise Development Programme (MEDEP) in 1998 to address issues regarding poverty among socially excluded groups by promoting and supporting them to start small scale enterprises that have the potential to bring them out of poverty (MOI, UNDP, Australian Aid, 2016).

The country's economic growth has averaged four percent over the last decade, and absolute poverty decreased to $23.8 \%$ in 2015 . However, there are large disparities in the rates of poverty by gender, social group and geographical area (GON, NPC, 2073). 
There are problems connected with procuring raw materials. There are equally important aspects pertaining to such allied matters as lack of finance for effecting bulk purchases, non-availability of quality raw materials, high market rates, and lack of facilities of transportation and so on (Gupta, 1985).

Jha (2010) stated that the operational problems and challenges as faced by the entrepreneurs affect their growth in rural areas. Since 2005, the Global Entrepreneurship Monitoring (GEM) database has continued to attract scholarly attention, and several other focused and special issues have appeared in multidisciplinary journals. Scholars have assessed the impact of financial institutions on entrepreneurship in differing conditions. For example, Roper and Scott (2009) discovered that women faced significantly more financial barriers during start up phases. Jones-Evans and Thompson (2009) report that though formal and informal investments appear to be concentrated in richer areas in the UK, informal investments tended to have a greater impact on equity capital within poorer regions. About 90 percent of the people in developing countries lack access to financial services from institutions, either for credit or savings (Roy \& Wheeler, 2006).

Roy and Wheeler (2006) identified a number of common practical issues and characteristics were found to inhibit (hinder/problem) the success of many entrepreneurs in Urban Far-West Africa (UFWA): most notably, limited access to capital, and lack of cooperation among possible business partners. Among those interviewed, one third considered lack of capital to be the most significant obstacle to their growth and success. Limited access to capital and credit may be one of the primary inhibitors of micro-enterprise growth and success in UFWA.

The lack of access to finance from commercial banks and special financial institutions has been found to be major constraint of the Micro and Small Enterprise (MSE) sector in Thailand, particularly for micro-enterprise. One of the major obstacles to be overcome is the role of collateral in assigning finance to borrowers (ILO, 2000).

FNCCI (2012) identified some of the key challenges; they were lack of commercialization primarily arising from issues such as lack of agro inputs (fertilizer, irrigation, etc), market access and market development, risk management (insurance) and lack of research and extension. Nepal Economic Growth Agenda (NEGA) recommendations were proposed to increase access to inputs, develop insurance programs and enhance research and extension through private sector involvement.

As stated by UN (2001) problems of one micro enterprise group (MEG) were quite different from those of another MEG. Most of the problems were concerned with the availability of raw materials, quality of products, price of the product, selling and distribution of the products, revenue from enterprise, availability of suitable technology, availability of 
credit (loan), availability of skilled labour, government support, training, monitoring and incentives, etc.

\section{Research Problem}

Nepal confronts with a number of economic challenges at present: low economic growth, low per capita income, higher level of poverty, poor social indicator, underdeveloped physical infrastructures, and high cost economy to higher cost of production. Most of the micro enterprises are operating with a little fund, local resources and local skills.

Entrepreneurship, which is a very challenging task itself, is for all businessmen or entrepreneurs. They have to face several obstacles as well as problems. They have their own goals and industrial aspirations to go ahead; they dream of new ventures. Ultimately they have to achieve them all at any cost. Entrepreneurs have to face several problems and obstacles in every part of their business world. Such problems may be different in developing and developed countries. However, least developed or developing countries like Nepal, entrepreneurs have been facing several problems day by day. Problems with respect to starting a new business, obtaining financial support, technical support, skilled manpower, raw materials, power energy, method of operation, lack of knowledge regarding management, accounting, marketing and legal problems, etc and etc. It is assumed that micro entrepreneurs possess a little knowledge, skills, capital, resources and market access to their products.

The researcher tries to find out answer of the following research questions.

- What types of financial problems are faced by the micro enterprises?

- What types of production/ operational and input related problems are faced by the micro enterprises?

\section{Research Objectives}

Main purpose of the study is to identify major problems of micro enterprises in

Baglung district and Parbat district. Other specific purposes of the study are as follows:

- To analyze financial problems of micro enterprises.

- To examine production/ operation and inputs problems of micro enterprises.

\section{Research Significance}

Micro enterprise is a most important element for economic development specially developing or less developed countries like Nepal due to scarce of required infrastructure and adequate capital. Micro enterprise is a crucial factor not only for low income and backward families in rural area to alleviate their poverty but also important to develop entrepreneurship in country. The result and findings of this research will be useful for academicians, researchers, concerned authorities and micro entrepreneurs themselves. 


\section{Research Limitation}

The research work covered only two districts of Nepal i.e. Parbat and Baglung from Dhaulagiri zone, Gandaki province of Nepal. The study is focused on the study of financial and operational problems of micro enterprises in Parbat and Baglung. The data and information regarding micro enterprises covered till the end of 2019. There is no availability of authentic data sources from where the researcher can collect the total numbers of micro enterprises in concerned districts. It has several reasons. First, there is no need to register micro enterprise in any government agencies; second, it is found elsewhere in the country and they are countless. However, the office of the MEDPA is the main sources of secondary data for the study purpose.

\section{Literature Review}

Salazar (1995) mentioned that some major problems of small industries that have been identified in several business conferences. which are mentioned as the absence of collateral guarantees in order to obtain credit from the bank, limited technical skills in production, limited working capital, limited technology of product design, equipment, and machinery, lack of managerial competence to meet the new challenges in facing competition in the international market, lack of information of foreign market situation, industry and trade and lack of professionalism in conducting business such as in business negotiations.

The conditions of infrastructure road, telephone, electricity, etc is among the most important determinants of the level of development and growth of small enterprises in rural areas. It has also played an important role in raising the productivity of small enterprises (Torri, 2012).

Jha and Updhyaya (2002) had analyzed the gaps in policy, legal and regulatory environment of micro and small enterprise (MSE) sector in Nepal. They have identified issue like lack of explicit policy for micro-enterprises, non-registration of MSEs, poor financial support to MSEs, and poor access to credit, difficulties of MSEs, in getting raw materials, utilities and other support service, poor institutional mechanisms, ineffective promotion of micro and small enterprises and entrepreneurs among host of their issues.

Ranabhat (2012) stated the main constraints/influencing factors regarding youth entrepreneurship development. According to Ranabhat, main constraints in finance are: lack of personal savings and resources, lack of securities and credibility, lack of business experience and skills, lack of knowledge, understanding, awareness of start-up financing possibilities, and lack of (successful) micro lending/finance and seed funding.

FNCCI and World Bank (1999) identified major problems/constraints faced by SMEs through a survey on 'Business Environment and manufacturing Performance in Nepal'. They were given the proportion in percentage: finance (Assess to finance, collateral, interest rate)- 
$14 \%$; infrastructure (electricity, road/transportation, water) nine percent; labour (shortage of skilled labour, labour turnover, unions/strikes)-seven percent and shortage of inputs (raw materials, unavailability of ports) four percent.

A report of Industrial Enterprise Development Institute (IEDI) (IEDI, 2014) stated the main hindering factors in business promotion of cottage and small industries in Nepal. According to the report of the research, the main hindering factors in promotion of micro, cottage and small business were irregularity in supply of electricity; shortage of labour force in local market and unavailability of required skilled labour with unemployment problem; high production cost and higher price due to low volume of production, high overhead and service cost, lower productivity of labour (therefore they were not able to compete with other products); lack of entrepreneurship desire in people (lack of risk bearing capacity, irregularity in supply of raw materials; growing trend of foreign employment so that lack of thinking of conducting their own business within country and lack of proper and clear-cut government rules and regulations with responsibility of the government, incentives to industries, registration of business, renewal of business, provision of taxes which creates problems to conduct business.

Center for Development and Governance (CDG) conducted a national conference on small and medium enterprise (SMEs) development in Nepal in May, 2001 (CDG, 2001). According to the proceeding of national conference, problems of SMEs development in Nepal were identified. Some of these problems are as follows:

i) Raw Materials and Machinery Supply: Over 90 percent of the total inputs represent cost of materials and supplies purchased. Most industries rely on local raw materials while some depend on raw materials imported from India or overseas,

ii) Financing requirements and capital: The SMEs typically face major obstacles in obtaining adequate financial resources for setting up, sustaining and upgrading their operations. The difficulties are attributed to several factors. Access to institutional credit for SMEs is limited in the context of individual entrepreneur's inability to contribute the equity capital and the collateral security. The Banks tend to be conservative in their evaluation of SMEs. Also, SMEs are often not familiar with various banks providing facilities to them.

\section{Methods and Materials}

Research methodology provides guideline to the research work. It is also known as road map of the research work. This study is based on mixed research design (quantitative and qualitative research). Data are collected from primary sources. However, a few data and information are also obtained from secondary sources. Primary data are collected through personal interview with entrepreneurs, observation of micro enterprises activities, focus group discussion with entrepreneurs and structured questionnaires. Secondary data are collected from 
the office of the Micro Enterprises Development for Poverty Alleviation (MED-PA), district office of the Cottage and Small Industries Development Board (CSIDB). Both quantitative and qualitative data are used wherever they are needed. Qualitative data are used acquired through Focus Group Discussion Programme (FGDP) with micro entrepreneurs of the respective districts. All micro entrepreneurs of both districts are assumed total population. Sample size is 361. For selecting respondents' multistage (three stage), sampling method was used. First, selection of district is based on purposive sampling method. Second, entrepreneur is selected on the basis of random sampling method. Third, only one respondent from each enterprise is interviewed to get ultimate information. Univariate analysis has been done to compute percentage or frequency distribution. Statistical Package for Social Survey (SPSS) 17.0 version as well as excel programme is to analyze the data.

Procedures of Qualitative Data Collection

To identify the real situation and problems of entrepreneurs, the researcher has conducted four focus group discussion programme (FGDP) i.e. first one was in Modi Rural Municipality ward number one Patichuar common facility center (CFC), second was at the office of district micro enterprise group association (DMEGA) of the Parbat district and the third was in Bihunkot CFC and the fourth was at the office of district micro enterprise group association (DMEGA) of the Baglung district. Sita Sharma, programme coordinator of MEDEP, Parbat district, had played the role of chief facilitator in Patichuar and Gyanushree Sharma, an active social worker as well as a teacher of government school, had played the role of chief mentor/facilitator in Bihunkot focus group discussion programme in Parbat district and Baglung district respectively.

President of the DMEGA, Parbat district and president of the DMEGA, Baglung district had also played the role of chief facilitator. These FGDP were conducted at the office of DMEGA in Kusma and Baglung, headquarter of the Parbat and Baglung district respectively. District program coordinators of MEDEP had helped to arrange everything needed for focusgroup-discussion programme. The members of DMEGA are represented from various MEGA and it covers all MEGA of the district. They possessed different features with separate activities of micro enterprises. To collect information regarding various micro enterprises at one spot is the main objective of the FGDP.

The members of DMEGA represented from various MEGA, all members of the DMEGA are also concerned with micro entrepreneurs. Each FGDP divided into two parts, at the beginning entrepreneurs introduced themselves includes their own name, types of the enterprise or MEG, types of goods or produce by them, date of commencement of the business. And in second round, they expressed their own experience regarding enterprise, strengths and weaknesses of the business, various problems, and so on. With the help of various equipment, the researcher kept record of the basic information about entrepreneurs in the first round and 
detail information in the second round. Participants felt comfortable in the programme while expressing their own experience in this sector. Chief facilitators were familiar with the entrepreneurs and locally recognized persons as well as familiar with the micro enterprise development programme (MEDEP).

\section{Results and Discussion}

Micro entrepreneurs faced several problems regarding financing. Due to the lack of sufficient funds, they were not able to buy raw materials, machine, equipment and tools and other service facilities in time. For example, Dhaka Udyog (industry), entrepreneurs are not able to buy the required materials in adequate volume and in time. Even if available, the volume or quantity of materials is very low. For example, in Patichaur in Parbat district entrepreneurs, who make handmade school bags or common carrying bags, due to lack of proper market, are not able to sell the goods on the one hand and on the other hand they are not able to generate revenue regularly. Such a situation also creates insufficiency of working capital.

\section{Results of Quantitative Data Analysis}

Various problems were faced by the enterprises as well as entrepreneurs from the time periods of starting the business to operating them by an individual and by a group. Through structured questionnaire, personal interviews and focus group discussion, some problems of micro enterprise and entrepreneurs were identified. There is also discussion about overall problems of entrepreneurship development in Nepal. Through review of literature and analyzing data, some problems are identified regarding entrepreneurship development in Nepal.

\section{Economic/ Financial Problems}

They have given eight options to identify economic/financial problems, they are as follows:

- Lack of working capital,

- problems of bad debts collection,

- lengthy loan procedures,

- high interest rate,

- lack of collateral vi valuation problem,

- not available loan from financial institution, and

- other problems. 
Table 1

Economic/ Financial Problems

\begin{tabular}{lllllllll}
\hline Particulars & Yes & \multicolumn{3}{c}{ No } & \multicolumn{3}{c}{ Could not Respond } & \multicolumn{2}{c}{ Total } \\
\cline { 2 - 9 } & $\mathrm{N}$ & $\%$ & $\mathrm{~N}$ & $\%$ & $\mathrm{~N}$ & $\%$ & $\mathrm{~N}$ & $\%$ \\
\hline Lack of working capital & 176 & 48.8 & 167 & 46.3 & 18 & 5.0 & 361 & 100 \\
Bad debt collection & 37 & 10.2 & 306 & 84.8 & 18 & 5.0 & 361 & 100 \\
Lengthy loan procedure & 23 & 6.4 & 320 & 88.6 & 18 & 5.0 & 361 & 100 \\
High interest rate & 55 & 15.2 & 288 & 79.8 & 18 & 5.0 & 361 & 100 \\
Lack of collateral & 17 & 4.7 & 326 & 90.3 & 18 & 5.0 & 361 & 100 \\
Valuation problem & 12 & 3.3 & 331 & 91.7 & 18 & 5.0 & 361 & 100 \\
Not available loan from & 14 & 3.9 & 329 & 91.1 & 18 & 5.0 & 361 & 100 \\
financial institution & & & & & & & & \\
Others & 7 & 1.9 & 336 & 93.1 & 18 & 5.0 & 361 & 100 \\
\hline
\end{tabular}

Note. Field Survey, 2019.

An attempt has been made to identify economic/financial problems through questionnaire. There is found that out of seven options of economic or financial related problems, respondents felt that lack of working capital, high interest rate on loan/credit and problems on collection of due amounts of sales are highly dominant to other types of problems. These problems occupy 48.8 percent, 15.2 percent and 10.2 percent respectively. Likewise, 6.4 percent respondents felt that lengthy loan procedure, 4.7 percent felt that lack of collateral, 3.3 percent respondents felt that valuation problem and 3.9 percent respondents felt that there was scarcity of loan from financial institutions. The result seems quite different from other study reports made earlier.

A research study revealed that (Shrestha, 2007) the 34.92 percent of respondents felt that loans were not available in time, 23.81 percent of respondents felt that the rate of interest was high; whereas 15.34 percent of respondents expressed that the process of loan arrangement was lengthy. Another 14.82 percent said that there exists the valuation problem and the 11.11 respondents opined that there are the problems of collateral while approaching the financial institutions for loan.

About 90 percent of the people in developing countries lack access to financial services from institutions, either for credit or savings (Rubinson, 2002).

It may be changed due to change in the behavior of financial institutions and increase in the number of such institutions. As the number of financial institutions increased, 
entrepreneurs have got alternative sources of such financial institutions and bankers need to change their behaviour for searching appropriate candidate of loan or credit.

Problems of Inputs and Operation/Production

Most of micro enterprises produce goods and services within villages and common facility centres, which were based on locally available raw-materials, skills, labour and other resources, in general. However, they still feel some problems regarding production or operation and inputs.

Short supply of various inputs affects the utilization of production capacity, whereas inadequacy of finance has affected the technological innovations and adaptation in the rural enterprises in Bihar. Lack of infrastructural facilities discourages new aspirants from venturing into industrial and business activities in rural areas (Jha, 2010).

\section{Table 2}

Problems of Inputs and Operation

\begin{tabular}{lllllllll}
\hline Particulars & Yes & & No & & \multicolumn{2}{c}{$\begin{array}{l}\text { Could not } \\
\text { respond }\end{array}$} & \multicolumn{2}{c}{ Total } \\
\cline { 2 - 8 } & $\mathrm{N}$ & $\%$ & $\mathrm{~N}$ & $\%$ & $\mathrm{~N}$ & $\%$ & $\mathrm{~N}$ & $\%$ \\
\hline $\begin{array}{l}\text { Raw materials are not } \\
\text { locally available }\end{array}$ & 133 & 36.8 & 224 & 62.0 & 4 & 1.1 & 361 & 100 \\
$\begin{array}{l}\text { Lack of quality raw } \\
\text { materials }\end{array}$ & 60 & 16.6 & 297 & 82.3 & 4 & 1.1 & 361 & 100 \\
$\begin{array}{l}\text { Not able to produce quality } \\
\text { finished goods }\end{array}$ & 54 & 15.0 & 303 & 83.9 & 4 & 1.1 & 361 & 100 \\
$\begin{array}{l}\text { Lack of skilled/trained } \\
\text { labor }\end{array}$ & 104 & 28.8 & 253 & 70.1 & 4 & 1.1 & 361 & 100 \\
$\begin{array}{l}\text { Lack of adequate supply of } \\
\text { electricity, road, water etc.) }\end{array}$ & 111 & 30.7 & 246 & 68.1 & 4 & 1.1 & 361 & 100 \\
$\begin{array}{l}\text { Valuation problem } \\
\text { Others }\end{array}$ & 12 & 3.3 & 331 & 91.7 & 4 & 1.1 & 361 & 100 \\
\hline
\end{tabular}

Note. Field Survey, 2019

Production and operation related problems are related to raw materials that are not available locally; lack of quality raw materials; not able to produce quality finished goods; lack of skilled/trained labor; lack of adequate supply of electricity, road, water etc infrastructures; 
problems regarding valuation of collateral and other problems related inputs, production and operations.

Most of the respondents stated that they had to feel the problems of raw material, supply of electricity, road, water, skill or trained labour, quality of raw material and quality of finished goods. However, out of 361 respondents, most of them do not feel these problems in the same way. Those who are faced with such problem feel that raw-materials are not easily available for entrepreneurs themselves. About 36.8 percent respondents feel it. 30.7 percent feel that there is problem of adequate supply of electricity, road, water, etc. 28.8 percent respondents feel that there is lack of skilled or trained labour.

Shrestha (2007) stated that the cottage and small-scale units have to depend on the suppliers for the raw materials and they have to procure them locally since they are not in a position to buy in huge quantities. The 18.14 percent respondents said that the raw materials were not locally available.

In a similar research works, Khatri, Chhetri and Karmacharya (2003) reported that around 38 percent of enterprises reportedly had faced problems in acquiring raw material for their enterprises. Among the problems faced, the short supply of raw materials in the local markets was the acute problem followed by the transportation problem and lengthy government process.

Zivetz (1992) noted that the problem of obtaining raw materials is the greatest headache for entrepreneurs, irrespective of the size of their undertaking. While industries dependent on external raw materials face major difficulties, even industries, which rely on domestic raw materials, encounter obstacles. This clearly shows that entrepreneurs are at the mercy of the agents for the inputs and when they cannot procure directly, their cost of production may go higher.

\section{Results of Qualitative Data}

It was observed during the field visit in both the districts: Parbat and Baglung districts. When, the researcher visited in common facility center (CFC) with the aim of conducting group discussion throughout the concerned entrepreneurs, those facts have been revealed. A CFC at Patichuar of Parbat district was the first attempt made to conduct a group discussion with the various categories of enterprises that came from different micro enterprise groups (MEGs). They expressed their problems as they had faced before starting the micro enterprise, during production process, and after production of goods and services i.e. marketing related problems. They also explained several other problems related to availability of raw materials, quality of goods, prices of the goods, market knowledge, technology related, financial related, skilled labour, sales related problems, etc. However, most of the micro enterprises are operating in rural area (Nepal) due to availability of raw materials, skills and resources (Karki, 2017). 
There is found various types of micro enterprise groups (MEGs) such as MEG related with Allo fiber and items; MEG related with Allo fiber and items; MEG related with offseasonal vegetables; MEG related with Bamboo products; Members of MEG related with incense stick; improved Aaron (Blacksmith's workshop); the members of the MEG related with bags and accessories and members of the MEG, related with beekeeping. They expressed their own problems. Major problems expressed by the different MEGs are as follows:

- Difficulty in the collection of raw materials from remote forest,

- Lack of raw materials. (or lack of availability of quality raw materials),

- Problems related with cooking, washing, barking, dyeing, weaving of Allo and Allo fiber,

- Lack of skilled labour/ shortage of farm labour,

- Lack of transportation, water supply/irrigations, electricity, cold storage facilities.

- Difficulty to protect of vegetables and fruits from various types of infections or diseases or lack of techniques of proper treatment,

- Heavily used pesticide/insecticide vegetables by other farmers (It is harmful for beekeeping farmers)

- Customers are not able to distinguish organic vegetables from non-organic vegetables in market

- High cost of production, low volume of production and lack of devotion on production of quality products.

- Lack of proper machine and tools for cutting/preparing incense sticks.

- Insufficient fund to buy the raw materials and machine/ equipment.

- Lack of suitable field of flowers for bees and lack of modern improved beehives.

- Lack of coal and wood in the local market (for blacksmith).

Although certain handicraft, organic foods (e.g. coffee), vegetables and fruits and environment friendly garments found a niche in the international market, export of MSE products from the country. Urban demand within the country itself also remained limited or nonexistent for many products. Both export and urban demands tend to be sensitive about quality, design and novelty of products that many MSE products continued not to fulfill. Production linkage based (intermediate) demand remained undeveloped to a large extent in the absence of adequate market research and supporting policies. 


\section{Findings}

Drawn on the basis of analysis of data and information, the major findings of the research area as follows:

- Out of seven options of economic or financial related problems, respondents felt that lack of working capital, high interest on loan/credit and problems on collection of due amount of sales are highly dominant problems.

- In the context of input and operation related problems, most of the respondents have to face the problems of raw materials, supply of electricity, road, water, skill or trained labour, quality of raw materials, and quality of finished goods.

- Besides above problems, major problems expressed by the different MEGs are as follows:

- High cost of production, low volume of production and lack of devotion on production of products.

- Lack of proper machine and tools.

- Lack of cold storage facility within district

- Difficulty to protect of vegetables and fruits from various types of infections or diseases or lack of techniques of proper treatment,

- Heavily used pesticide/insecticide vegetables by other farmers (it is harmful for beekeeping farmers)

- Customers are not able to distinguish organic vegetables from non-organic vegetables in market. (Lack of awareness of organic fruits and vegetables)

- Lack of transportation, water supply/irrigations, electricity facilities, etc.

\section{Conclusion}

Several problems are faced by micro entrepreneurs and micro enterprises. Most of the micro enterprises are conducted by an entrepreneur; therefore, there is no more difference between problems faced by entrepreneurs and problems of enterprise.

Micro entrepreneurs faced several problems regarding financing. Due to the lack of sufficient funds, they were not able to buy raw materials, machine, equipment and tools and other service facilities in time. For example, cutting and sewing enterprises or Dhaka Udyog (industry), entrepreneurs are not able to buy the required materials in adequate volume and in time. Even if available, the volume or quantity of materials is very low. Most of the micro entrepreneurs expressed that they have faced critical problems such as lack of working capital, high interest rate charge on loan and bad debts collection. One study showed that 90 percent of 
the people in developing countries lack access to financial service from institutions, either for credit or savings (Rubinson, 2002).

High cost of production due to shortage of farm labour, low volume of production, infrastructure related problems, problems related with availability and collection of raw materials, poor quality of raw materials, lack of cold storage for preserving pershible goods like fruits and vegetables, lack of warehouse for keeping finished goods, lack of skilled/trained labour, lack of adequate supply of electricity and water and access of road transportation etc. are major input and production related problems. Zivetz (1992) noted that the problem of obtaining raw materials is the greatest headache for entrepreneurs, irrespective of the size of their undertaking.

Various problems of micro enterprises are found. A problem of one enterprise is quite differing from other enterprises under similar group. There is not covered all types of problems of micro enterprises in this research. Therefore, it is recommended that further research should be conducted to identify other types of problems face by the micro enterprises. It is suggested that government and other concerned authorities should try to overcome problems faced by micro enterprises.

\section{References}

Centre for Development and Governance (CDG). (2001). Small and medium enterprise development in Nepal-proceeding of national conference, (Edited by Masky, Bishwa and Manandhar, Narayan), May. Kathmandu: CDG.

Federation of Nepal Chambers of Commerce and industry (FNCCI) and World Bank

(WB) (1999). Business environment and manufacturing performance in Nepal. Kathmandu: FNCCI and WB.

Federation of Nepalese Chambers of Commerce \& Industry (FNCCI). (2012). Nepal Economic Growth Agenda (NEGA) Report, 2012. Kathmandu: FNCCI.

Government of Nepal (GON), Ministry of Industry (MOI). (2011). Industry Policy 2011. Kathmandu: MOI.

Government of Nepal, Ministry of Industry, Commerce and Supplies. (2075). Operation Directives of MEDPA-2070 (3rd amendment). Kathmandu: Government of Nepal, Ministry of Industry, Commerce and Supplies.

Gupta, A. D. (1985). The development of small scale industries in India and the operational problems related to them: with special reference to Bihar State, Ph.D. Thesis submitted to Faculty of Commerce: Patan University, Patna. 
Industrial Enterprise Development Institute (IEDI) (2014). A study report of internal impact evaluation of entrepreneurship development training. Kathamandu: IEDI (2070 B.S.)

ILO. J. (2000). Resolution concerning statistics of employment in the informal sector. Fifteenth International Conference of Labour statisticians (January 1993), in Current International Recommendations on Labour Statistics. Geneva: ILO.

Jha, N. K. (2010). Problems and prospects of rural entrepreneurship in Bihar: A case study. Patna University, 34, 178-186.

Jha, P., \& Upadhyaya, K. (2002). Micro and small enterprises, policy review in Nepal: Analysis of policy gaps. HURDEC.

Jones-Evans, D., \& Thompson, P. (2009). The spatial dispersion of informal investment at a regional level: evidence from the UK, European Planning Studies, 17(5), 659-75.

Karki, B. B. (2013). Micro enterprises in Nepal prospect and practice. Janapriya Journal of Interdisciplinary Studies, 2(1), 20-27.

Karki, B. B. (2017). Practie of micro enterprises in Nepal. Janapriya Journal of Interdisciplinary Studies, 10(1), 20-27.

Khatri-Chhetri, J. B., \& Karmacharya, K. (2003). Micro and small enterprises policy review in Nepal survey of micro and small enterprises' owner's/managers third component report. Kathmandu: GON, ILO, UNDP/ MEDEP.

Ministry of Industry, UNDP, Australian Aid. (2016). Annual Progress Report of Micro Enterprise Development Programme (MEDEP)- 2016. Ministry of Industry, UNDP, Australian Aid.

Government of Nepal (GON), National Planning Commission. (2073). Fourteen Plan (FY 2073/74-2075/2076). Kathmandu: GON, NPC

Ranabhat, B. (2012). A report on youth entrepreneurship development in Nepal. Kathamndu: Industrial Enterprise Development Institute (IEDI).

Roper, S., \& Scott, J. M. (2009). Perceived financial barriers and the start-up decision: an econometric analysis of gender differences using GEM data, International Small Business Journal, 27(2), 149-71.

Roy, M. \& Wheeler, D. (2006). A survey of micro-enterprises in urban West 
Africa: Drivers shaping the sector. Development in Practice, 16(5), 452-464.

(Published by Taylor \& Francis Ltd on behalf of Oxfam GB).

Rubinson, M. S. (2002). The microfinance revolution: sustainable finance for the poor. Washington D.C.: World Bank office of the Publishes.

Salazar, J. M. (1995). Problem and prospects of micro and small industries in the process of economic liberalization in Southeast Asia, small and micro enterprises in a period of economic liberalization: Opportunities and challenges, Paper and Proceedings of an Asian Regional workshop on Policy Environment for Micro and Small Enterprises in a Period of Economic Liberalization: Bangkok, February, Edited by Rizwanul Islam, (ILO)) South Asia Multidisciplinary Advisory Team (SAAT) International Labour organization (ILO).

Shrestha, R. (2007). Entrepreneurship development in Nepal: A Doctoral Thesis Submitted to Faculty of Management, Tribhuvan University, Nepal.

Torri, M. C. (2012, March). Innovative farmer's institutions and market imperfections: New opportunities and challenges for the Ayurbedic sector and small -scale enterprise in India, The Journal of Entrepreneurship, 21(1), 59-90.

United Nations (UN). (2001). Growing Micro and Small Enterprises in LDCs, the Missing Middle Geneva: UN.

Zivetz, L. (1992). Private Enterprise and The State in Modern Nepal: Madras, Oxford University Press. www.lawcommission.gov.np/industrialenterprises act 2073, (amendenment-2075). 